九州大学学術情報リポジトリ

Kyushu University Institutional Repository

\title{
WOOD-WASPS OR HORN-TAILS OF THE AMAMI-OSHIMA ISLAND, WITH DESCRIPTION OF A NEW SPECIES (HYMENOPTERA : SIRICOIDEA)
}

Togashi, Ichiji

Hirashima, Yoshihiro

https://doi.org/10.5109/2429

出版情報: ESAKIA. 19，pp.185-189，1982-11-25. Entomological Laboratory，Faculty of Agriculture, Kyushu University バージョン：

権利関係 : 


\title{
WOOD-WASPS OR HORN-TAILS OF THE AMAMI-OSHIMA ISLAND, WITH DESCRIPTION OF A NEW SPECIES (HYMENOPTERA：SIRICOIDEA) *
}

\author{
ICHIJI TOGASHI \\ Ishikawa Prefectural College of Agriculture, \\ Nonoichi-machi, Ishikawa 921, Japan \\ and \\ YoshiHIRo HiRASHIMA \\ Entomological Laboratory, Faculty of Agriculture, \\ Kyushu University, Fukuoka 812, Japan
}

\begin{abstract}
A bstract
A new species of wood wasp, Hyperxiphia nodai Togashi, is described from the Amami-Oshima Island. The Oriental horntail, Eriotremex formosanus, is recorded from Japan for the first time.
\end{abstract}

So far as we are aware, only a single species of the wood wasp has been known from the Amami-Oshima Island. This is Genoxiphia hirashimai Okutani, 1965. In this paper one of us (Togashi) describes, based on the material recently collected by Mr. R. Noda of Kyushu University, a new species of Hyperxiphia and we report the occurrence of the Oriental horntail, Eriotremex formosanus from this island. This is the first record of Eriotremex from Japan.

We are thankful to Mr. Noda for the interesting material.

\section{Family SIRICIDAE}

\section{E riotremex formosanus (Matsumura)}

Specimen examined: 1 female, Amami-Oshima Island, June 29, 1980 (R. Noda). This was collected on a path in the central forest area of the island.

Eriotremex is new to Japan. According to D. R. Smith (1978), this genus has been recorded from India, Vietnam, Malaysia. Philippines, Indonesia and North America. He suggests, however, that Eriotremex formosanus, the sole

* Contribution from the Entomological Laboratory, Faculty of Agriculture, Kyushu University, Fukuoka (Ser. 3, No. 122). 


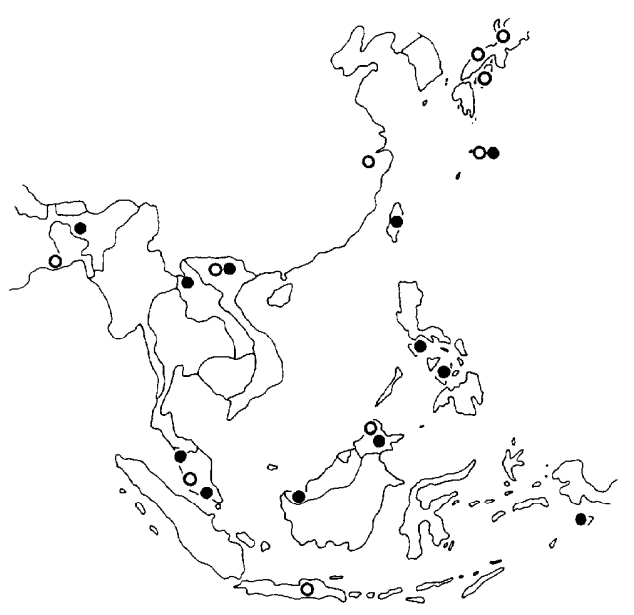

Fig, 1. A map showing the distribution of Eriotremex ( $\bullet$ ) and Hyperxiphia (0).

representative of the genus in North America is an introduced species.

The genus Eriotremex Benson is closely related to the genus Tremex Jurine but these are separable by the following characters:

Basal part of radial cell divided by the radial cross vein about half as long as apical part in Eriotremex (Fig. 3), about as long as apical part in Tremex (Fig. 6) ; 7th and 8th tergites densely hairy in Eriotremex (Fig. 4), not hairy but with fine pubescence in Tremex; precornal basin strongly subreticulatepunctate in Eriotremex, very finely coriaceous in Tremex; and in female, cerci present in Eriotremex (Fig. 4), absent in Tremex.

\section{Family XIPHIDRIIDAE}

\section{Hyperxiphia nodai Togashi, new species}

Female : Length $9 \mathrm{~mm}$.

Body including antennae black; central portion of mandible reddish brown. Wings smoky; stigma and veins brown to dark brown. Legs brownish black to black; claws reddish brown.

Head seen from above rather globose (Fig. 7) ; postocellar furrow slightly depressed (Fig. 8); lateral furrows ill-defined; OOL: $P O L$ : $O C L=1.0$ : 1.0: 3.2; median fovea present (Fig. 8); clypeus as shown in Fig. 8; mandible quadridentate ; labial palpus 4-segmented (Fig. 10) ; maxillary palpus 5-segmented (Fig. 11) ; occipital carina sharp, complete ; temple with submarginal furrow (Figs. 7 and 9) ; malar depression as shown in Fig. 9.

Antenna 14-segmented, slightly shorter than costa of fore wing (the ratio about 1.0: 1.3) ; scape curved (Fig. 12), nearly as long as 3rd segment; rela- 
tive lengths of basal segments about $2.1: \mathbf{1} .0: 1.8: 1.1: 1.1$ in lateral view.

Praescutum obtuse ; in lateral view, median scutal line shallow, apical half of prescutal sutures rather narrow with deep apical portion, and posterior halves of prescutal sutures rather shallow; cenchri small (Fig. 13).

Wing venation : similar to H.leucopoda (Takeuchi), though radial cross vein interstitial with 2nd cubital cross vein, and nervulus interstitial with basalis (Fig. 14).

Hind basitarsus nearly as long as following 3 segments combined. Claw with a rather small tooth near the middle (Fig. 15).

Propodeum with an oblique furrow along the central line (Fig. 13) ; sheath as shown in Fig. 16.

Sculpture. Area behind suprorbital line and temples covered with rather shallow and scattered punctures, shining (Figs. 7 and 9) ; area below suprorbital line including malar space rather strongly, coarsely and irregularly sculptured (Fig. 7) ; pronotum deeply, coarsely and subreticulately sculptured ; mesonotum strongly, irregularly and rugosely subreticulate ; meso- and metascutellum irregularly and rugoso-subreticulately sculptured, but latero-posterior portion of mesoscutellum smooth (Fig. 13) ; mesopleuron irregularly and ru.
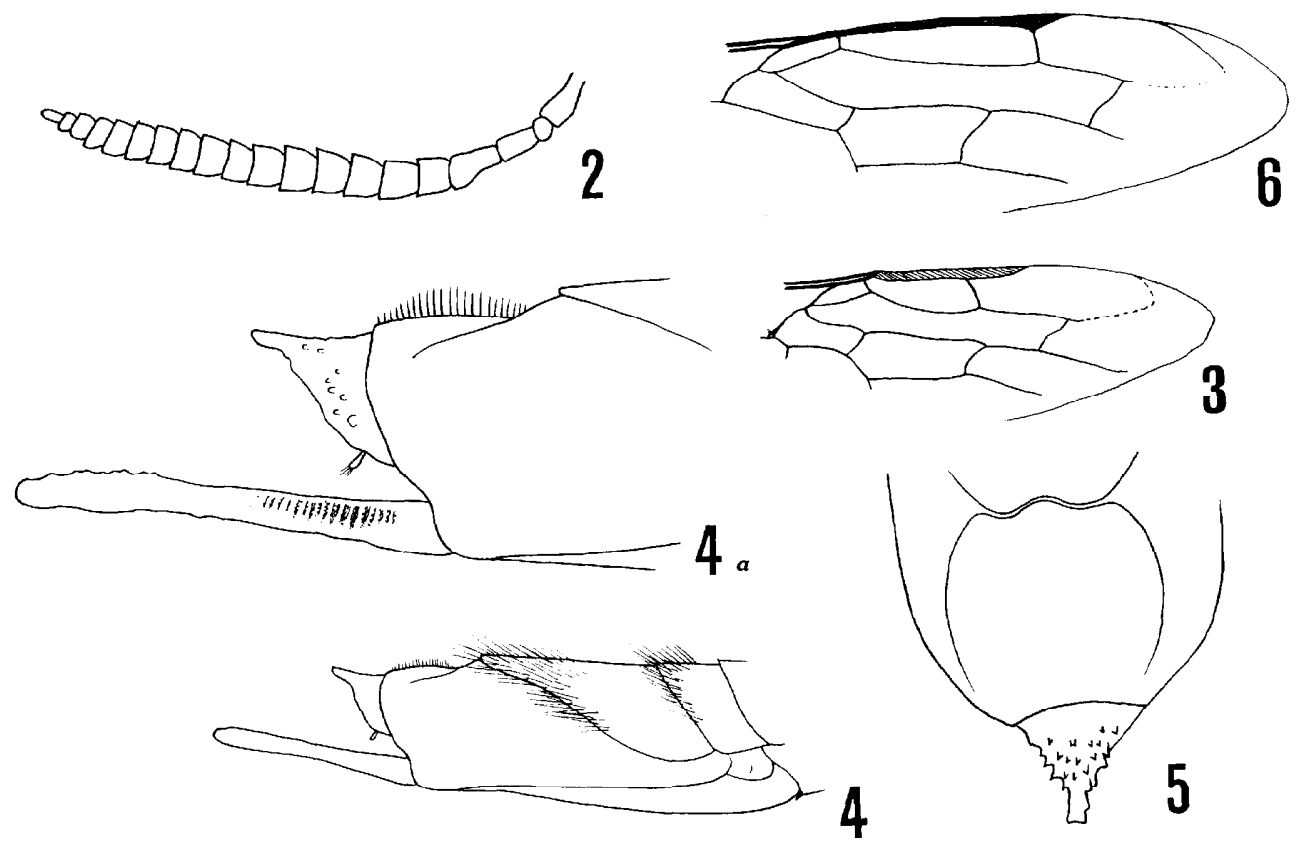

Figs. 2-5. Eriotremex formosanus (Matsumura). 2: Antenna, lateral view. 3: Apical portion of right fore wing. 4: Caudal portion of abdomen, lateral view. 4 a: Cornus and sheath, lateral view. 5: Precornal basin. Fig. 6. Tremex fuscicornis Fabricius. Apical portion of right fore wing. 

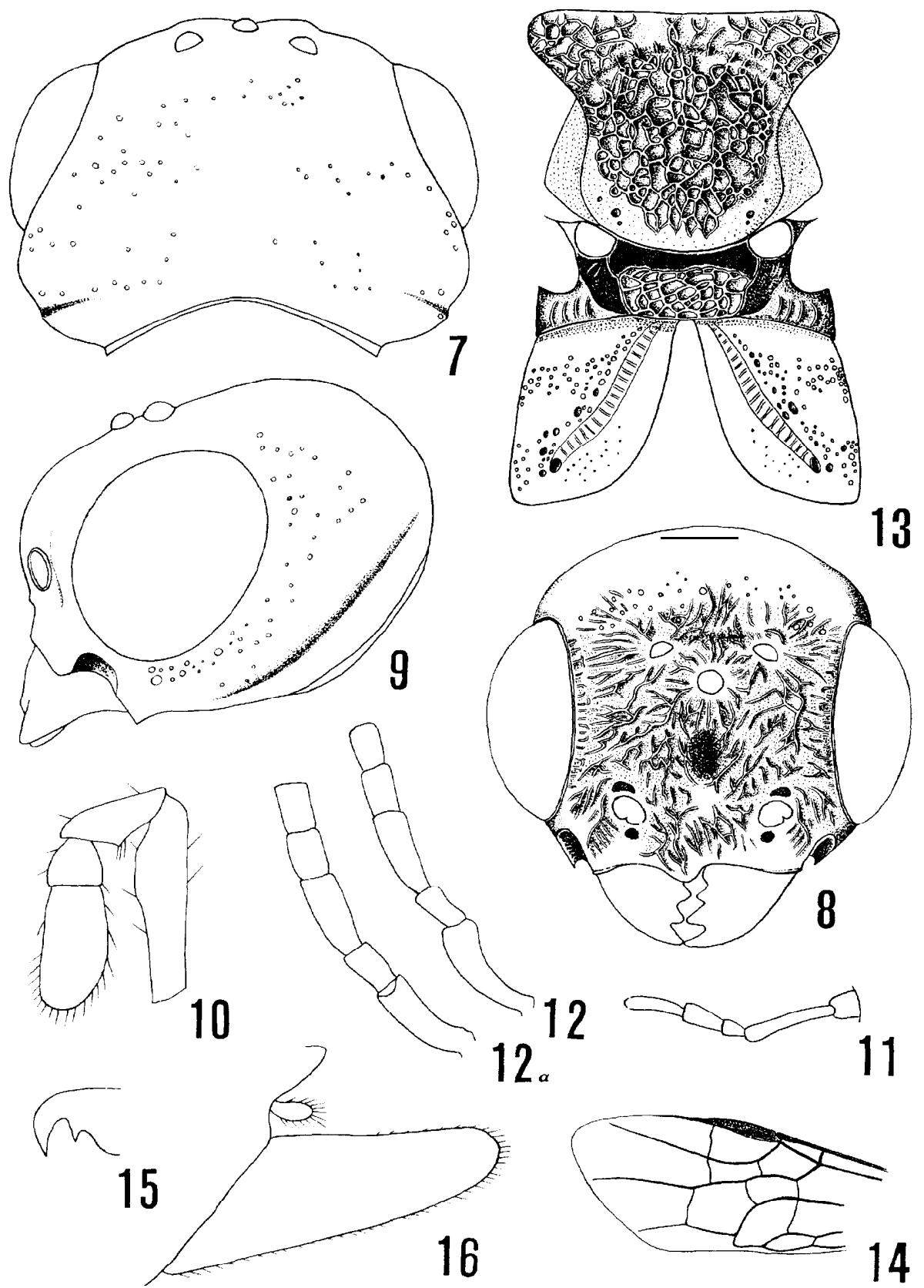

Figs. 7-16. Hyperxiphia nodai Togashi, new species. 7: Head, dorsal view. 8: Do, frontal view. 9: Do., profile. 10: Labial palpus. 11: Maxillary palpus. 12: Antenna, basal 5 segments, dorsal view. 12 a: Do., lateral view. 13: Scutellum and propodeum. 14: Apical portion of left fore wing. 15: Claw. 16: Sheath, lateral view. 
goso-subreticulately sculptured; oblique furrow along the central line of propodeum crenulate (Fig. 13), lateral portion of oblique furrow covered with distinct and scattered punctures (Fig. 13) ; lateral portions of 2nd and 3rd tergites distinctly and coarsely punctate; lateral portions of 4 th to 9 th tergites with setigerous punctures; posterior halves of 2 nd to 4 th tergites except for posterior margins with minute punctures.

Distribution: Japan (Amami-Oshima Island).

Type material: Holotype female (Type No. 2384, Kyushu Univ.), AmamiOshima Island, June 29, 1980 (R. Noda), collected on a path in the central forest area.

Remarks. According to the literature, this new species is close to Hyperxiphia melanaria (Mocsáry) from Vietnam, but is easily distinguished from the latter by the coloration of the legs (the trochanters, basal portion of the hind tibia and hind basitarsus white in melanaria), the coloration of the wings (hyaline in melanaria), and the number of the antenna1 segments (16segmented in melanaria). The Japanese species of Hyperxiphia may be separable by the following key.

\section{K E т то The Japanese species of Hyperxiphia}

1. Head rufous ; wing hyaline; legs entirely yellowish white; sheath short

- Head black

leucopoda (Takeuchi)

2. Legs brownish black to black; wing smoky; antenna 14-segmented; sheath

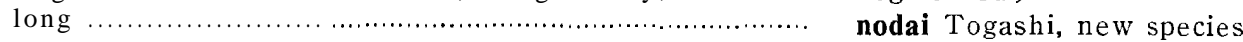

- Legs entirely yellowish white; wing hyaline; antenna 12- to 13-segmented; sheath short nakanishii (Takeuchi)

\section{References}

Benson, R. B. 1943. Studies in Siricidae, especially of Europe and Southern Asia. Bull. Ent. Res., 34: 27-50.

Maa, T. 1949. A synopsis of Asiatic Siricoidea with notes on certain exotic and fossil forms. Notes d'Ent. Chinoise, 8: 11-189.

Mocsáry, A. 1904. Siricidarum species quinque novae. Ann. Mus. Nat. Hungarici, 11: 496498.

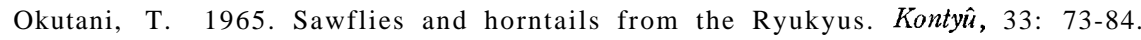

Smith, D. R. 1978. Hymenopterorum Catalogus, Pars 14, pp. 193. Hague-Holland.

Takeuchi, K. 1938. A systematic study on the suborder Symphyta of the Japanese Empire (1). Tenthredo, $2: 173-229$. 